\title{
Natural enemies of the latania scale, Hemiberlesia lataniae (Hemiptera: Diaspididae) in Egypt
}

\author{
Mona Moustafa and Shaaban Abd-Rabou
}

Plant Protection Research Institute, Agricultural Research Center, Dokki, Giza, Egypt.

\section{ABSTRACT}

The latania scale, Hemiberlesia lataniae (Signoret) (Hemiptera: Diaspididae) is a dangerous pest in different locations in Egypt. During the present work, 17 species of natural enemies were collected from samples of $H$. latania. These are: Aphytis aonidiae (Mercet), Aphytis chilensis Howard, Aphytis lingnanensis Comepre, Aphytis mytilaspidis (Le Baron) (Hymenoptera: Aphelinidae), Chilocorus bipustulatus L. (Coleoptera: Coccinellidae), Chrysoperlla carnae Steph. (Neuroptera: Chrysopidae), Coccinella undecimpunctata L (Coleoptera: Coccinellidae), Encarsia aurantii (Howard), Encarsia lounsburyi (Berlese and Paoli) (Hymenoptera: Aphelinidae), Exochomus flavipes Thunb. (Coleoptera: Coccinellidae) and Habrolepis aspidioti Compere and Annecke (Hymenoptera: Encyrtidae), Marietta leopardina Motschulsky (Hymenoptera: Aphelinidae), Orius laevigatus Fieb. (Hemiptera: Anthocoridae), Pharoscymnus various Kirsch., Rodalia cardinals Muls (Coleoptera: Coccinellidae), Scymnus syriacus Mars. (Coleoptera: Coccinellidae) and Syrphus corollae Fabricius (Diptera: Syrphidae). Abundance of the latania scale, H. lataniae natural enemies were evaluated in different locations in Egypt, representing various bioclimatic regions during two successive years 2009-2010. The results indicated that the parasitoid, H.aspidioti the most abundant species associated with $H$. lataniae infested mango trees in Giza. The maximum rate of parasitism reached 9.1 and $7.3 \%$ in October, 2009 and 2010, respectively. The percentage of parasitism ranged from 0.1 to $9.1 \%$ in the first year and from 0.3 to $7.3 \%$ in the second year. The predator $C$. carnae was the most abundant species and occurred all over the years under investigation on $H$. lataniae on olive trees in Alexandria and the maximum number was 25 individuals /60 leaves and 15 twigs in July in the first year and 17 individuals/60 leaves and 15 twigs in June in the second year. Keys for parasitoids and predators associated with the latania scale, $H$. lataniae are included.

Key Words: Population dynamics, armored scale insects, Hemiberlesia lataniae, parasitoids and predators.

\section{INTRODUCTION}

The latania scale, Hemiberlesia lataniae (Signoret) (Hemiptera: Diaspididae) is considered to be a serious pest in many areas of the world, including Egypt (Danzig and Pellizzari, 1998). Latania scale is a highly polyphagous species that has been recorded hosts belonging to 280 genera in 80 plant families (Davidson and Miller, 1990). It attacks vegetative growing, flowering, fruiting and post-harvest stages and it infests all aerial parts. The presence of $H$. lataniae can be detected by abnormal coloring and some distortion of leaves, twigs and fruit, and as pitting of the bark of stems. Heavy infestation can cause dieback of twigs and branches (Kosztarab, 1996). $H$. lataniae is one of the commonest cosmopolitan species of diaspidids (Williams and Watson, 1988), it is widespread throughout the tropical and subtropical areas of 
the world and under glass in temperate regions (Nakahara, 1982) and it is recorded as an economic species in Egypt by El-Minshawy et al. (1974) and Williams and Greathead (1990).

In Egypt, there are three generations per year for this pest (El-Minshawy et al., 1971). Natural enemies usually control populations of latania scale in field conditions. However, this will only occur where insecticides are not applied (Stoetzel and Davidson, 1974). In New Zealand (1993) Hill et al. imported and released three predatory beetle species (Chilocorus bipustulatus (Linnaeus), C. infernalis (Linnaeus) and C. cacti (Linnaeus)) (Coleoptera: Coccinellidae) and two predatory mite species (Hemisarcoptes coccophagus Meyer and H. cooremani Thomas) for the biological control of armored scale insects including latania scale. $H$. coccophagus has established on $H$. lataniae infestations on Lombardy poplar (Populus nigra var. Italica) shelter trees at three sites. Detailed studies at one of the release sites over a period spanning 9 to 24 months after release, showed that densities of $H$. lataniae in samples with mites fell to less than $20 \%$ of the level in control trees. In Egypt (1999) Abd-Rabou recorded 2 parasitoid species associated with latania scale. These are Aphytis mytilaspidis (LeBaron) (Hymenoptera: Aphelinidae) and Haprolepis aspidioti Compere and Annecke (Hymenoptera: Encyrtidae). Later the same author (2006) stated that Aphytis lingnanensis Comepre (Hymenoptera: Aphelinidae) is one of the most important parasitoid associated with armored scale insects including $H$. lataniae. No country side work was conducted of the predators of the latania scale in Egypt.

The aim of this work is to study the occurrence of natural enemies associated with the latania scale, $H$. lataniae in Egypt.

\section{MATERIALS AND METHODS}

Infested crops with, $H$. lataniae will be examined in the field, using a pocket lens during 2009-2010. The parts of the plant from different crops will be collected and placed separately in paper bags for further examination in the laboratory. Materials will be kept in a well-ventilated container until the emergence of any parasitoids. Identification of parasitoids will be made by examining mounted adults in Hoyers medium according to the methods of (Abd-Rabou, 2002). In the other hand a survey of the predators of $H$. lataniae was carried out in different location in Egypt during 2009-2010. Infested host plants by the latania scale was examined in the field, using a pocket lens. Leaves, leaflet, stems and fruits from different host plants were collected and placed separately in paper bags for further examination in the laboratory. Predators was made by examining their mounted adults on cards according Noyes (1982).

Abundance of parasitoids and predators of $H$. lataniae was carried out on mango trees in Giza, Ismailia, Sharqiya and on olive in Alexandria, Fayoum, Ismailia, Northern Coast. The plant areas selected for these investigations received no chemical control measures for several years. Ten trees of each host plant almost similar in age, size, shape and growth condition were randomly chosen for sampling at a month intervals for each location. On each sampling, 60 leaves and 15 twigs $(20 \mathrm{~cm} . l o n g)$ were chosen at random and examined immediately in the field for counting the number of predators. Thereafter, the leaves and twigs were kept in a closed paper bags and transferred to the laboratory for further examination. In case of parasitoids each leaf and twig was stored in a well-ventilated emergence glass tube and monitored daily for parasitoid emergence. Rate of parasitism was determined by dividing the number of emerging parasitoid from each by the number of hosts scale existing. 
Simple correlation and regression values were calculated to obtain information about the relationships between the population of $H$. lataniae and its natural enemies.

\section{RESULTS AND DISCUSSION}

\section{The parasitoid, Aphytis aonidiae (Mercet) (Hymenoptera: Aphelinidae)}

Diagnosis: This is holarctic species and male unknown. Occiput without such bars on sides of foraman, mouth margin and malar sulcus usually not fuscous. Propodeal crenulae non overlapping. Mesoscutum 6 setae, marginal vein 8 setae, marginal fringe 0.2 as long as the width of disc. Thoracic setae dark; ovipositor1.6 times as long as midtibia, 4.6 times as long as sheath. Posterior margin of scutellum narrowly lined with blackish fuscous.

Abundance: During the present work the parasitoid was rarely on $H$. lataniae on olive trees in Alexandria. The percentage of parasitism ranged from 0 to $0.7 \%$ and from 0 to 0.6 during the first and second years, respectively (Fig. 1). This species was recorded by Abd-Rabou and Hayat (2003) attacking Aonidia lauri Bouche (Hemiptera: Diaspididae) for the first time in Egypt.

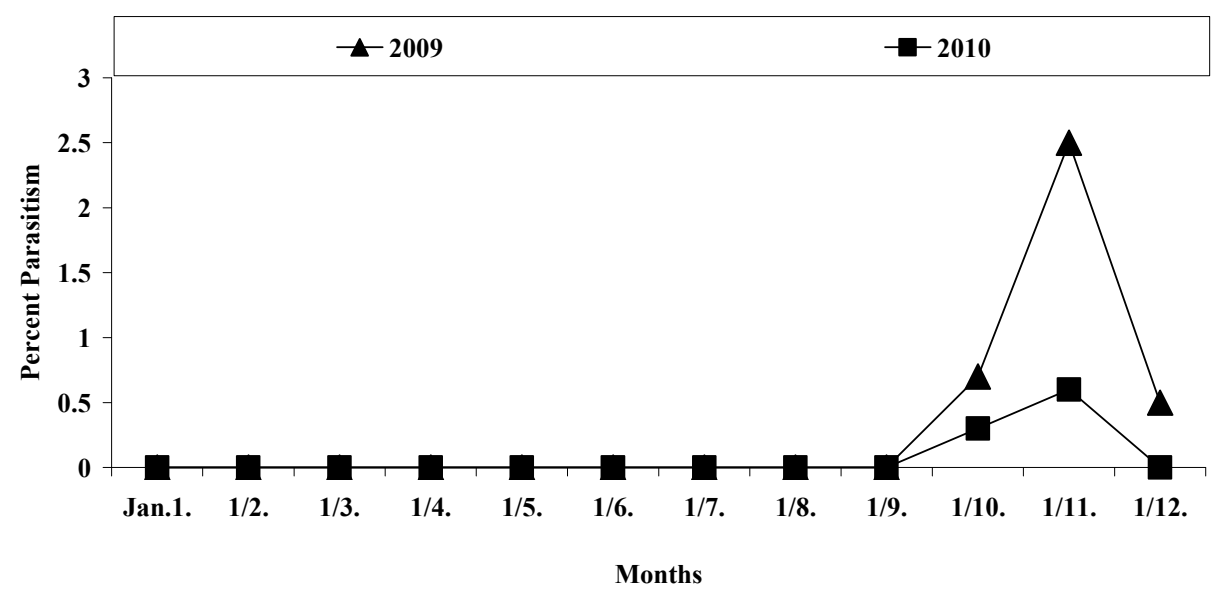

Fig. (1): Population dynamics of he parasitoid, Aphytis aonidiae associated with the latania scale, Hemiperlisia latania on olive trees in Alexandria Governorate .

Statistical analysis showed that simple correlation and regression between the population of the parasitoid, A. aonidiae and the mean number of the latania scale, $H$. lataniae were non-significant $(\mathrm{r}=0.32, \mathrm{~b}=0.21$ and $\mathrm{r}=0.17, \mathrm{~b}=0.19$ during the first and second years, respectively).

\section{The parasitoid, Aphytis chilensis Howard (Hymenoptera: Aphelinidae)}

Diagnosis: This is cosmopolitan and biparental species.Occiput with a fuscous to black bar on each side of foramen, the mouth margin and or malar sulcus sometimes fuscous. First segement of funicle small, triangular, smaller than F2. Club 3-4 times as long as wide and 9 sensilla; setae on head readily visible; propodeum 0.6 as long as scutellum, 3.5 times as long as metanotum; non overlapping 11 crenulae. Male antennae 4-segmented, antennal scape pale and pedicel faintly dusky.

Abundance: The presented data in Fig. 2 showed that the maximum rate of parasitism reached 1.8 and $3.5 \%$ in October 2009 and 2010, respectively. The percentage of parasitism ranged from 0 to $1.8 \%$ in the first year and from 0 to 3.5 in the second year. This species was recorded for the first time in Egypt by Abd-Rabou and Hayat (2003). Abd-Rabou (2006) stated that the maximum parasitism rate of $A$. 
chilensis on Chrysomphalus dictyospermi (Morgan) (Hemiptera: Diaspididae) on Ficus nitida in El-Minya was 3.3\% during December with an average rates $0.7 \%$.

Statistical analysis showed that simple correlation and regression between the population of the parasitoid, A. chilensis and the mean number of the latania scale, $H$. lataniae were non-significant $(\mathrm{r}=0.38, \mathrm{~b}=0.41$ and $\mathrm{r}=0.23, \mathrm{~b}=0.36$ during the first and second years, respectively).

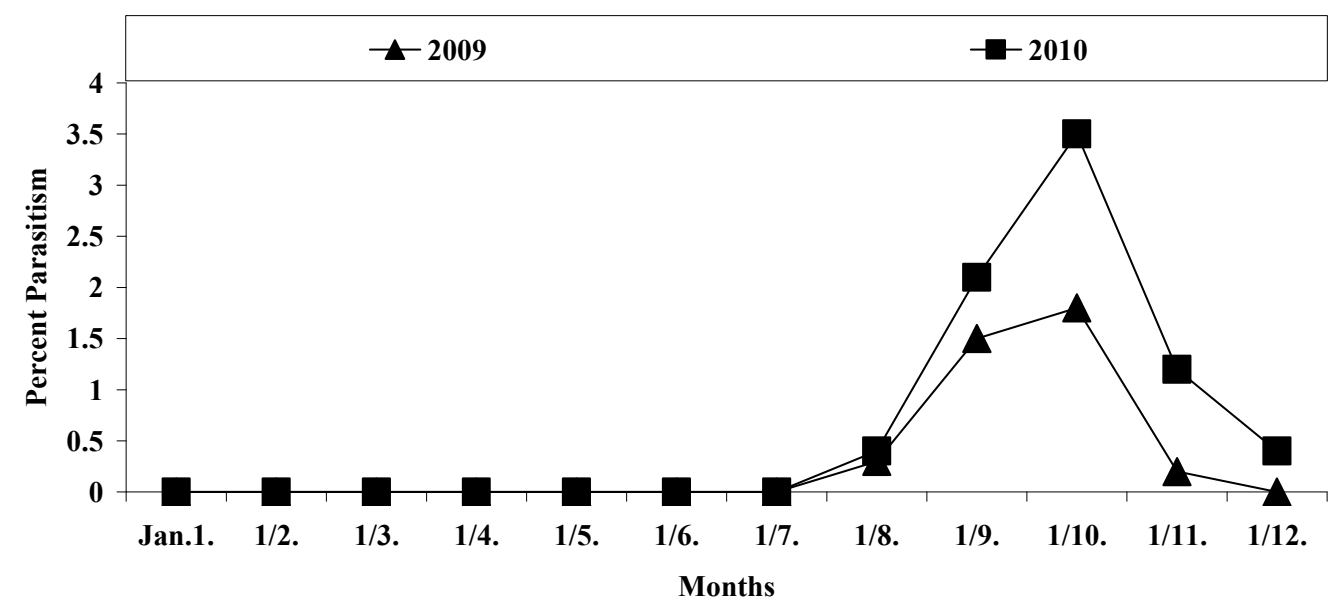

Fig. (2): Population dynamics of the parasitoid, Aphytis chilensis associated with the latania scale, Hemiperlisia Iatania on olive trees in Ismailia Governorate .

\section{The parasitoid, Aphytis lingnanensis Comepre (Hymenoptera: Aphelinidae)}

Diagnosis:. This is a cosmopolitan and biparental species. Occiput without such bars on sides of foramen, mouth margin and malar sulcus usually not fuscous. Body setae slender and pale. Club about 0.5 of mid tibia, mesoscutum usually with $10-12$ setae; delta of fore wing with 30-50 setae. Propodeum 0.6 as long as scutellum, 4.7 times as long as metanotum, large and overlapping 9 crenulae. Ovipositor 1.9 times as long as midtibia, 3.7 times as long as sheath and 0.5 as long as midtibia. Tergite VII 2 setae, tergite VIII 4 setae and syntergum 5-8 setae.

Abundance: The presented data in Fig. 3 showed that the maximum rate of parasitism reached 1.5 and $1.8 \%$ in October 2009 and 2010, respectively. The percentage of parasitism ranged from 0 to $1.5 \%$ in the first year and from 0 to 1.8 in the second year. This species was recorded for the first time in Egypt by Hafez (1988).

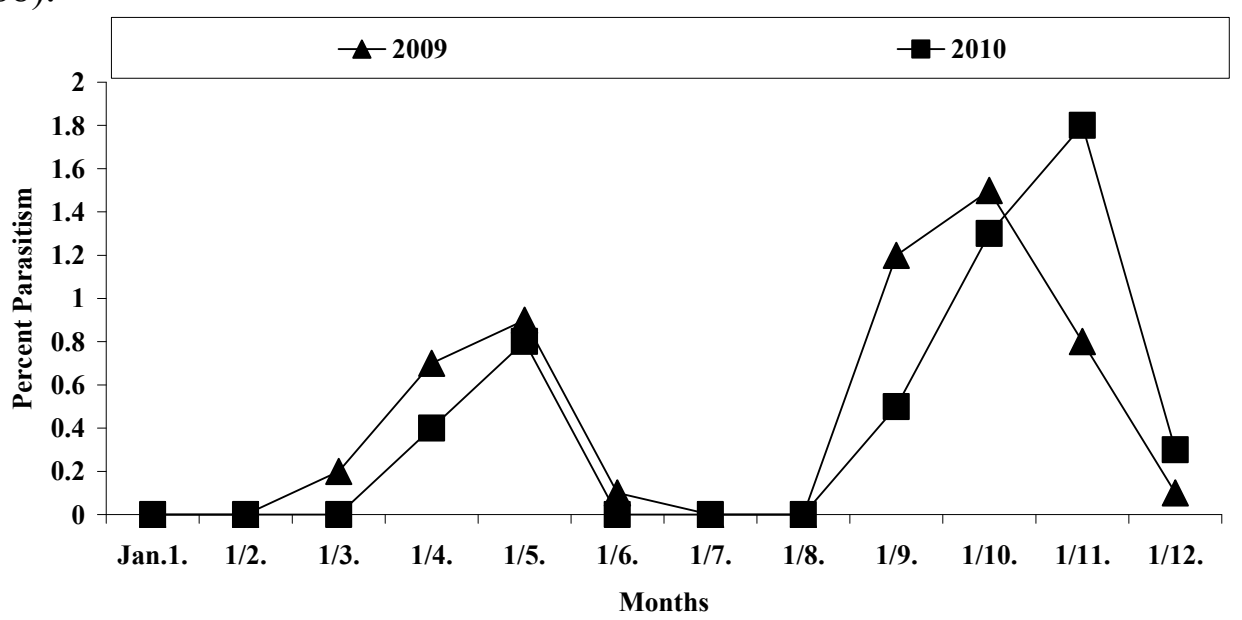

Fig. (3): Population dynamics of the parasitoid, Aphytis lingnanensis associated with the latania scale, Hemiperlisia latania on mango trees in Sharqyia Governorate . 
Abd-Rabou (2006) stated that the maximum parasitism rates of A. lingananensis on Parlatoria ziziphi (Lucas) (Hemiptera: Diaspididae) on Citrus sp. in Giza was 43.2\% during July, with an average rates $24.9 \%$.

Statistical analysis showed that simple correlation and regression between the population of the parasitoid, A. lingnanensis and the mean number of the latania scale, $H$. lataniae were non-significant $(\mathrm{r}=0.18, \mathrm{~b}=0.16$ and $\mathrm{r}=0.21, \mathrm{~b}=0.19$ during the first and second years, respectively).

4. The parasitoid, Aphytis mytilaspidis (Le Baron) (Hymenoptera: Aphelinidae)

Diagnosis:. This is a cosmopolitan, biparental and uniparental species. Occiput without such bars on sides of foramen, mouth margin and malar sulcus usually not fuscous, mandibles well developed. Propodeal crenulae distinct, rounded, non overlapping, pigmented; thoracic sterna dusky. Meososcutum 13 setae; marginal vein 6 setae and marginal fringe 0.2 as long as width of disc.

Abundance: The presented data in Fig. 4 showed that the maximum rate of parasitism reached 2.4 and $3.5 \%$ in November 2009-2010, respectively. The percentage of parasitism ranged from 0 to $2.4 \%$ in the first year and from 0 to 3.5 in the second year. Priesner and Hosny (1940) recorded this species for the first time in Egypt all over the Nile Delta. Abd-Rabou (2006) stated that the maximum parasitism rates of A. mytilaspidis on Parlatoria oleae Leonardi (Hemiptera: Diaspididae) on Prumus arminaca in Qalyubiya was 66.0\% during Nov., with an average rates 30\%.

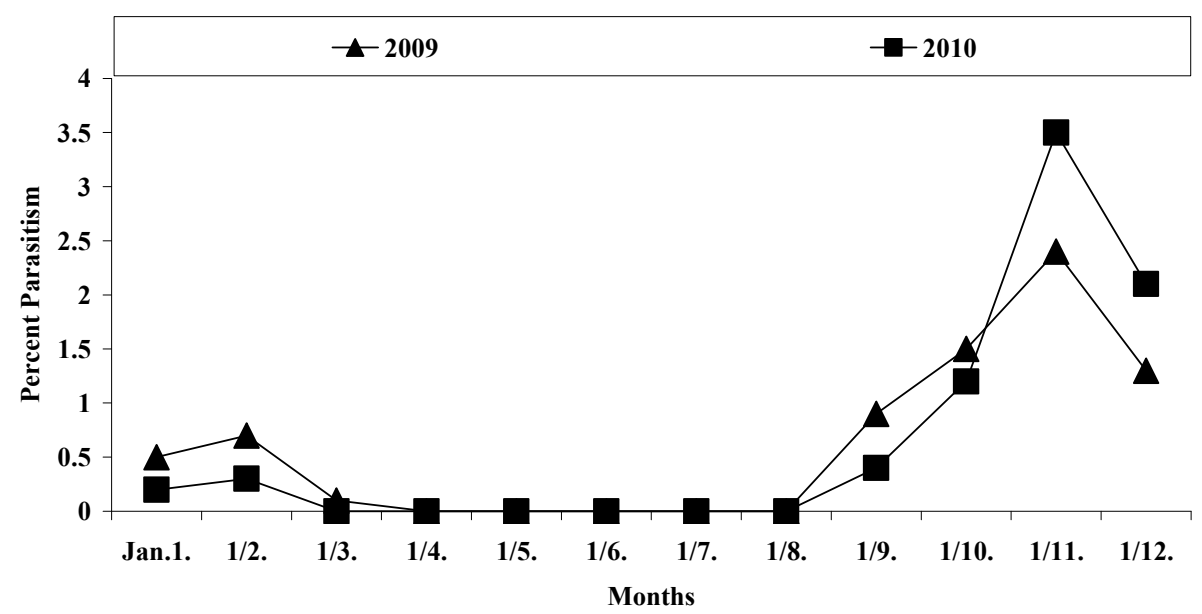

Fig. (4): Population dynamics of the parasitoid, Aphytis mytilaspidis associated with the latania scale, Hemiperlisia latania on olive trees in Northern Coast Governorate.

Statistical analysis showed that simple correlation and regression between the population of the parasitoid, $A$. mytilaspidis and the mean number of the latania scale, $H$. lataniae were non-significant $(\mathrm{r}=0.33, \mathrm{~b}=0.28$ and $\mathrm{r}=0.18, \mathrm{~b}=0.19$ during the first and second years, respectively).

5. The predator, Chilocorus bipustulatus L. (Coleoptera: Coccinellidae)

Diagnosis: This species has three pairs of legs, tarsi appearing 3-3-3, but actually 4-44 , head often concealed by pronotum, antennae short with a 3- to 6-segmented club, this Ladybird is small to medium in size $(2-8 \mathrm{~mm})$, its body is in round helmet shape, it was bright orange in colour with dark edges on the wing-cover base.

Abundance: During the present work this predator was rarely on $H$. lataniae on mango trees in Giza. Ten and eight individuals/60 leaves and 15 twigs only collected during the first and second years, respectively (Fig.5). This species recorded here associated with the latania scale, $H$. lataniae for the first time in Egypt. 


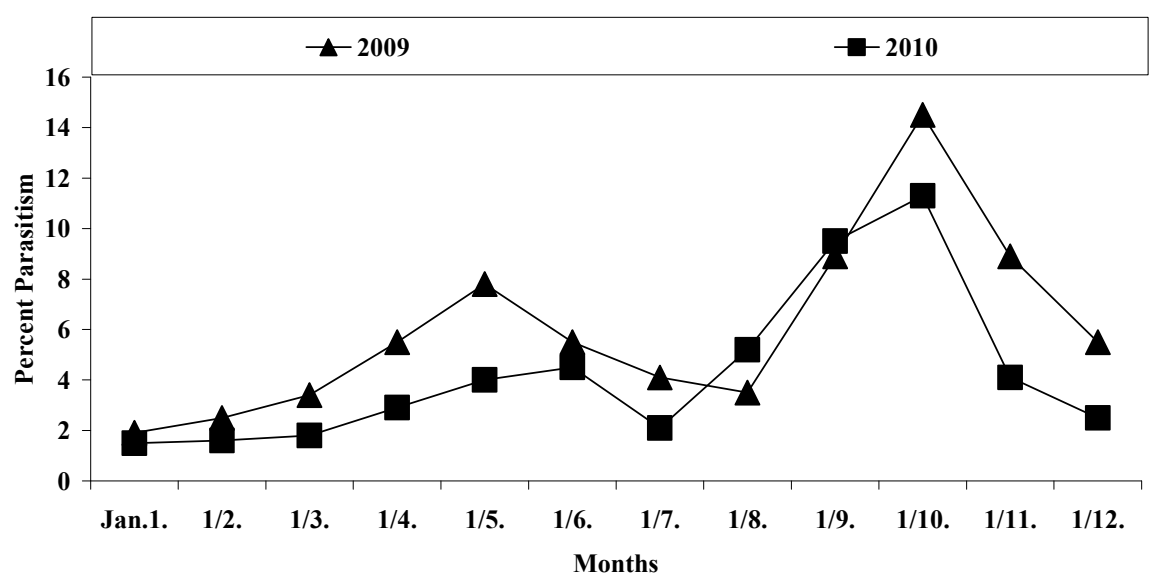

Fig. (5): Population dynamics of the parasitoid, Encarsia aurantii associated with the latania scale, Hemiperlisia latania on olive trees in Northern Coast Governorate.

Statistical analysis showed that simple correlation and regression between the population of the predator, C. bipustulatus and the mean number of the latania scale, $H$. lataniae were non-significant $(\mathrm{r}=0.31, \mathrm{~b}=0.27$ and $\mathrm{r}=0.17, \mathrm{~b}=0.18$ during the first and second years, respectively).

\section{The predator, Chrysoperlla carnae Steph. (Neuroptera: Chrysopidae )}

Diagnosis: Four membranous wings, with the forewings and hindwings about the same size, and with many veins. Adult green lacewings are pale green, about 12-20 $\mathrm{mm}$ long, with long antennae and bright, golden eyes. They have large, transparent, pale green wings and a delicate body

Abundance: During the present work this predator was occurred all over two years under investigation on $H$. lataniae on olive trees in Alexandria and the maximum number was 25 individuals/60 leaves and 15 twigs in July in the first year and 17 individuals /60 leaves and 15 twigs in June in the second year (Fig.6). This species recorded here associated with the latania scale, H. lataniae for the first time in Egypt. Statistical analysis showed that simple correlation and regression between the population of the predator, $C$. carnae and the mean number of the latania scale, $H$. lataniae were significant $(\mathrm{r}=0.78, \mathrm{~b}=0.79$ and $\mathrm{r}=0.81, \mathrm{~b}=0.82$ during the first and second years, respectively).

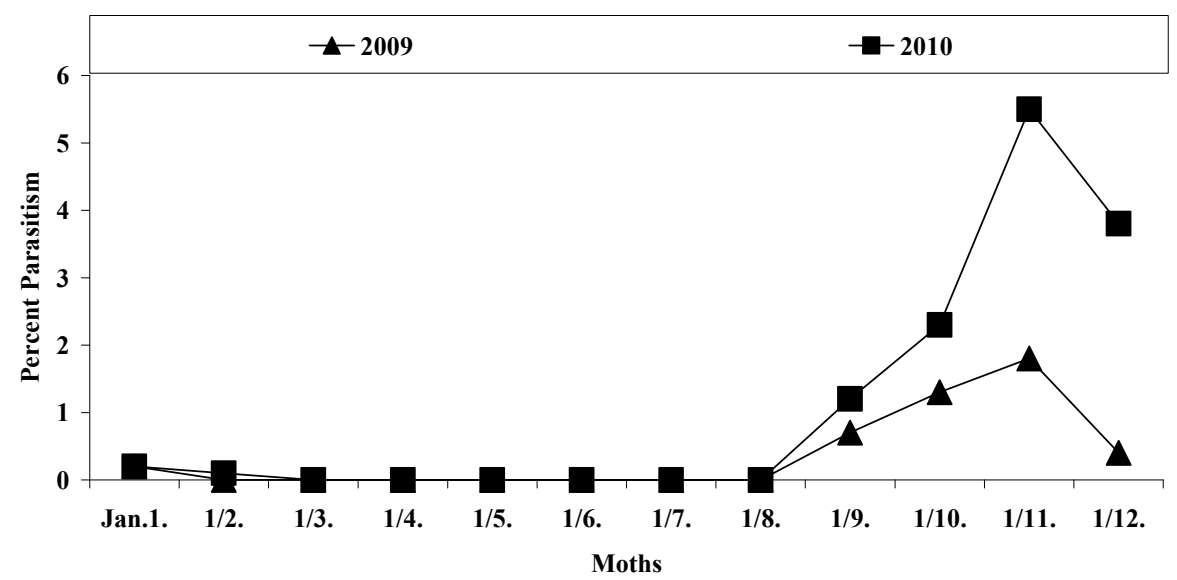

Fig. (6): Population dynamics of the parasitoid, Encarsia lounsburyi associated with the latania scale, Hemiperlisia latania on olive trees in Fayoum Governorate . 


\section{The predator, Coccinella undecimpunctata L (Coleoptera: Coccinellidae)}

Diagnosis: Forewings are modified into hard, leathery wing-cases (called elytra) that meet in a line down the back. The hind wings are membranous, folded beneath the elytra Postcoxal line not curved forward at apex Antennae7-segmented

Abundance: During the present work this predator was rarely on H. lataniae on olive trees in Fayoum. Fourteen individuals /60 leaves and 15 twigs only collected during the first and second years, respectively (Fig.7). This species recorded here associated with the latania scale, $H$. lataniae for the first time in Egypt.

Statistical analysis showed that simple correlation and regression between the population of the predator, $C$. undecimpunctata and the mean number of the latania scale, $H$. lataniae were non-significant $(\mathrm{r}=0.37, \mathrm{~b}=0.30$ and $\mathrm{r}=0.18, \mathrm{~b}=0.19$ during the first and second years, respectively).

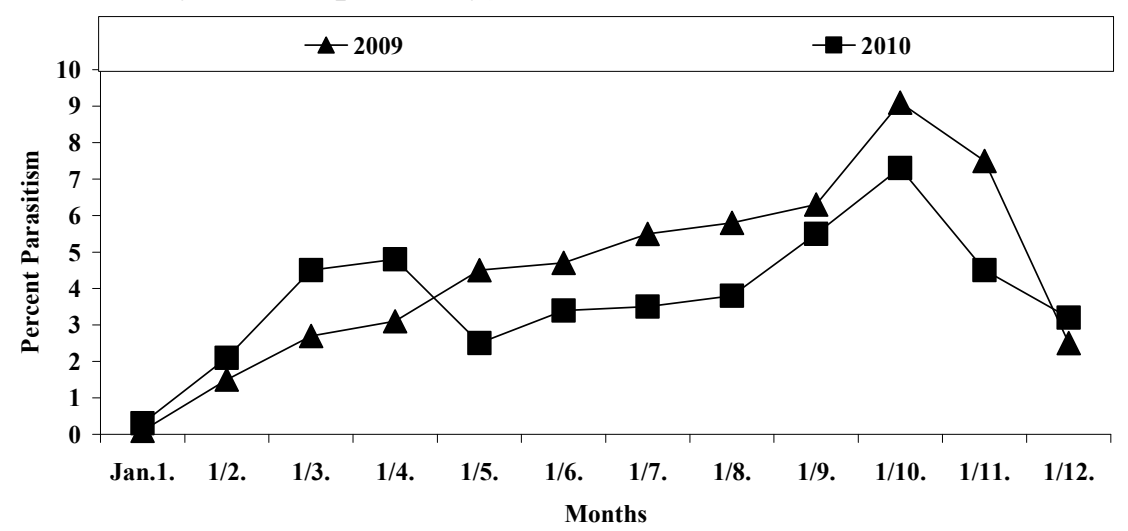

Fig. (7): Population dynamics of the parasitoid, Habrolepis aspidioti associated with the latania scale, Hemiperlisia latania on mango trees in Giza Governorate.

\section{The parasitoid, Encarsia aurantii (Howard) (Hymenoptera: Aphelinidae)}

Diagnosis: Face without dark brown cross bands above the toruli, gaster except apex of T7, largely brown to dark brown. Side lobes of mesoscutum each with two or fewer setae. Antennal club 3-segmented, ovipositor very short, clearly much shorter than mid tibia.

Abundance: Data represented in Fig. 8 showed that E. aurantii is one of the effective parasitoid attacking some armored scale insects. The parasitoid E. aurantii which associated with H. lataniae infested Olea sp. in Northern Coast.

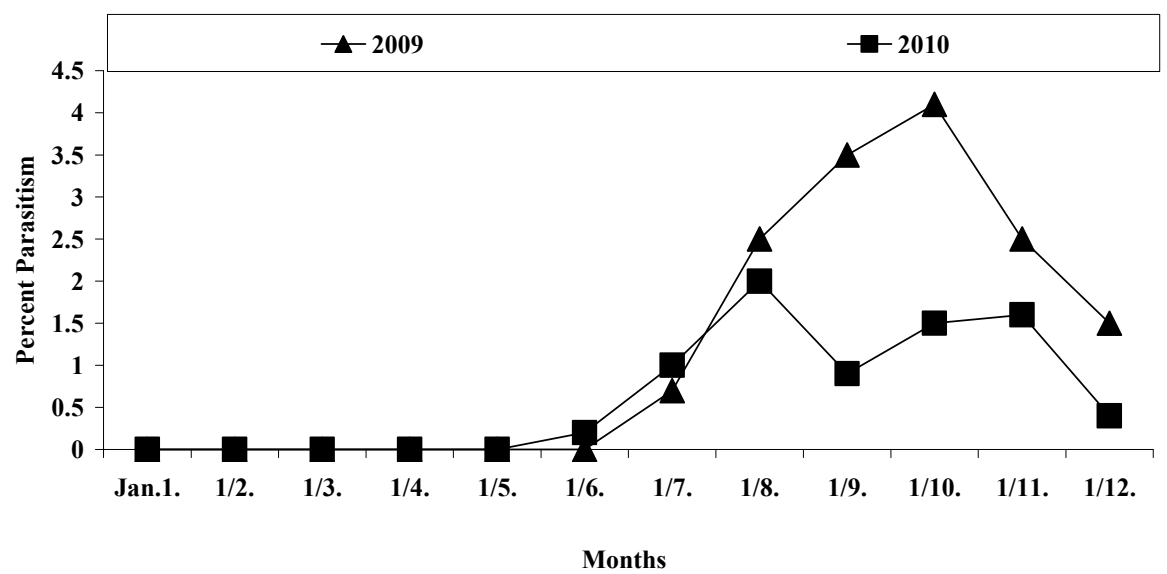

Fig. (8): Population dynamics of the hyperparasitoid, Marietta leopardina associated with the latania scale, Hemiperlisia latania on mango trees in Giza Governorate . 
The maximum rate of parasitism reached 14.5 and $11.3 \%$ in October, 2009 and 2010, respectively. The percentage of parasitism ranged between 1.9 and $14.5 \%$ during the first year and from 1.5 to $11.3 \%$ during the second year, respectively. This species was recorded for the first time in Egypt, by Hafez (1988). About 44000 individuals of E. aurantii was released on olive trees infested by P. oleae in Northern Coast, the parasitism rates increased from 44\% to $71 \%$ (Abd- Rabou, 2001).

Statistical analysis showed that simple correlation and regression between the population of the parasitoid, E. aurantii and the mean number of the latania scale, $H$. lataniae were significant $(\mathrm{r}=0.78, \mathrm{~b}=0.74$ and $\mathrm{r}=0.76, \mathrm{~b}=0.78$ during the first and second years, respectively).

9. The parasitoid, Encarsia lounsburyi (Berlese \& Paoli) (Hymenoptera: Aphelinidae)

Diagnosis: Body largely pale, longest seta on marginal fringe of fore wing less than the maximum width of the wing disc. Submarginal vein of fore wing with 1 seta.

Abundance: The presented data in Fig. 9 showed that the maximum rate of parasitism reached 1.8 and 5.5\% in November 2009 and 2010, respectively. The percentage of parasitism ranged from 0 to $1.8 \%$ in the first year and from 0 to 5.5 in the second year. This species was recorded for the first time in Egypt by Priesner and Hosny (1940). Abd-Rabou (2000) recorded this species associated with 13 species of armored scale insects in Egypt. He recorded the effective role of this parasitoid on the armored scale insects.

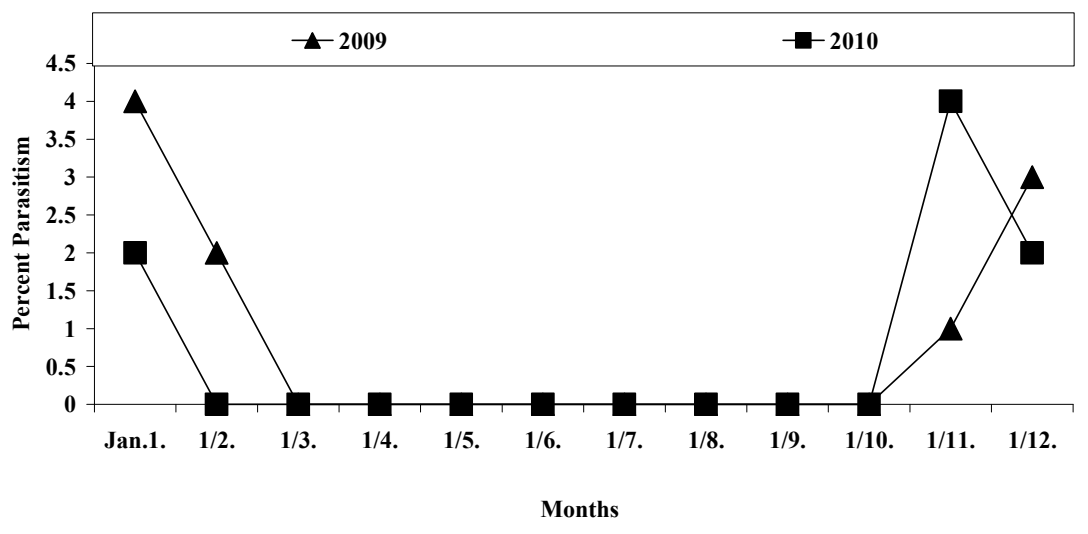

Fig. (9): Population dynamics of the predator, Chilocorus bipustulatus associated with the latania scale, Hemiperlisia latania on mango trees in Giza Governorate .

Statistical analysis showed that simple correlation and regression between the population of the parasitoid, E. lounsburyi and the mean number of the latania scale, $H$. lataniae were non-significant $(\mathrm{r}=0.21, \mathrm{~b}=0.26$ and $\mathrm{r}=0.11, \mathrm{~b}=0.14$ during the first and second years, respectively).

10. The predator, Exochomus flavipes Thunb. (Coleoptera : Coccinellidae )

Diagnosis: Forewings are modified into hard, leathery wing-cases (called elytra) that meet in a line down the back. The hind wings are membranous, folded beneath the elytra. Postcoxal line on first abdominal sternum curved forward at apex complete.

Abundance: During the present work this predator was rarely on H. lataniae on olive trees in Alexandria. Eight and 20 individuals/60 leaves and 15 twigs only collected during the first and second years, respectively (Fig.10). This species recorded here associated with the latania scale, $H$. lataniae for the first time in Egypt. Statistical analysis showed that simple correlation and regression between the population of the predator, E. flavipes and the mean number of the latania scale, $H$. 
lataniae were non-significant $(\mathrm{r}=0.27, \mathrm{~b}=0.23$ and $\mathrm{r}=0.19, \mathrm{~b}=0.21$ during the first and second years, respectively).

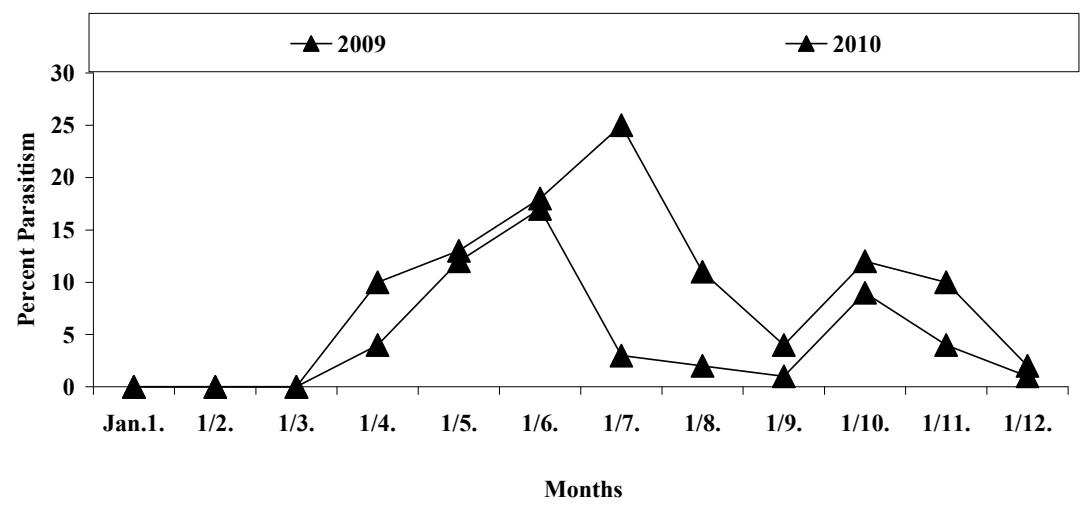

Fig. (10): Population dynamics of the predator, Chrysoperlla carnae associated with the latania scale, Hemiperlisia latania on olive trees in Alexandria Governorate.

\section{The parasitoid, Habrolepis aspidioti Compere \& Annecke (Hymenoptera: Encyrtidae).}

Diagnosis: Females with large conspicuous, lamelliform setae on scutellum and smaller suberect ones on head at fronto-occipital margin. Apex of fore wing distinctly infuscated and provided with coarse setae beyond hyaline transverse cross band. Base of fore wing with a fine setae extending based in an acuminate area almot to base of wing, antennal funicle segment I-IV transverse, V usually like wise.

Abundance: Data represented in Fig. 11 showed that the abundance of the parasitoid $H$. aspidioti which associated with $H$. lataniae infested mango trees in Giza. The maximum rate of parasitism reached 9.1 and 7.3\% in October, 2009-2010, respectively. The percentage of parasitism ranged from 0.1 to $9.1 \%$ in the first year and from 0.3 to $7.3 \%$ in the second year. This species was recorded for the first time in Egypt by Priesner and Hosny (1940). This species reported as an effective parasitoid on different armored scale insects in different locations in Egypt by AbdRabou (1997).

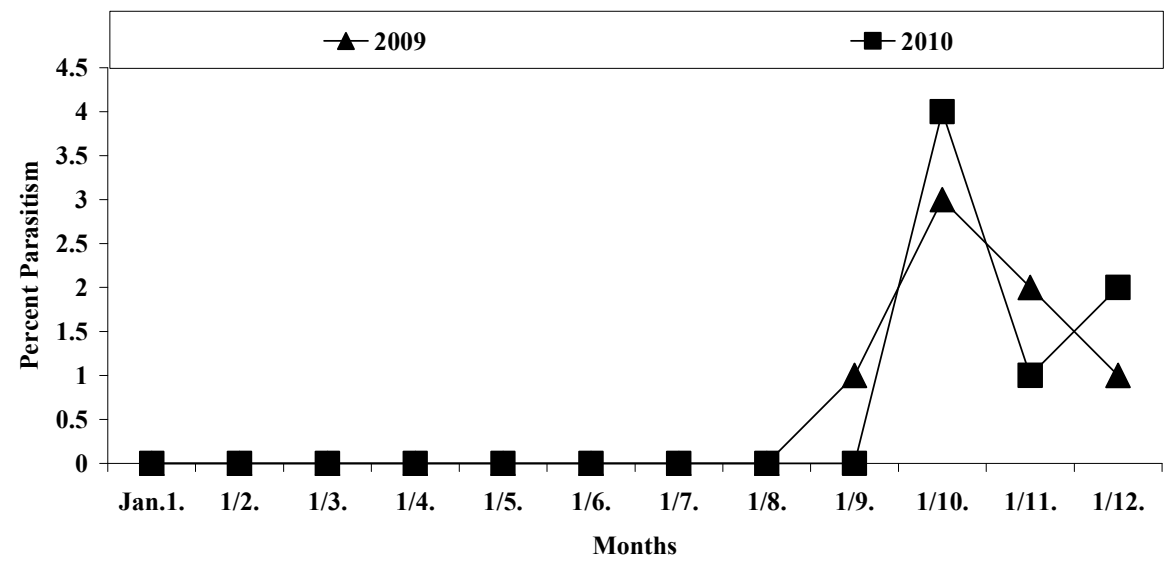

Fig. (11): Population dynamics of the predator, Coccinella undecimpunctata associated with the latania scale, Hemiperlisia latania on olive trees in Fayoum Governorate .

Statistical analysis showed that simple correlation and regression between the population of the parasitoid, $H$. aspidioti and the mean number of the latania scale, $H$. lataniae were significant $(\mathrm{r}=0.87, \mathrm{~b}=0.89$ and $\mathrm{r}=0.76, \mathrm{~b}=0.89$ during the first and second years, respectively). 
12. The hyperparasitoid, Marietta leopardina Motschulsky (Hymenoptera: Aphelinidae)

Diagnosis: Antennal scape less than 6 times as long as wide, or with one or two brownish bands or spots; anntennal scape with the band short; extending cauded from about middle of ventral margin; propodeum distinctly shorter than, metanotum; apex of fore wing without infuscate band in middle, mesoscutum 4 setae.

Abundance: Data represented in Fig. 12 showed that the dynamics of the hyperparasitoid M.leopardina which associated with $H$. lataniae infested mango trees in Giza. The maximum rate of parasitism reached 4.1 in October, 2009 and 1.6 in November, respectively. The percentage of parasitism ranged from 0 to $4.1 \%$ in the first year and from 0 to 1.6 in the second year. This species was recorded for the first time in Egypt by Priesner and Hosny (1940). It is a hyperparasitoid of different species of armored and soft scale insects in Egypt (Abd-Rabou, 2003). He mentioned that M. leopardina was reared out of 48 Hemipterous insects. The survey covered 16 governorates in Egypt. Classically orders, families and species of the host insects associated with this hyperparasitoid are given together with locality and month of abundance.

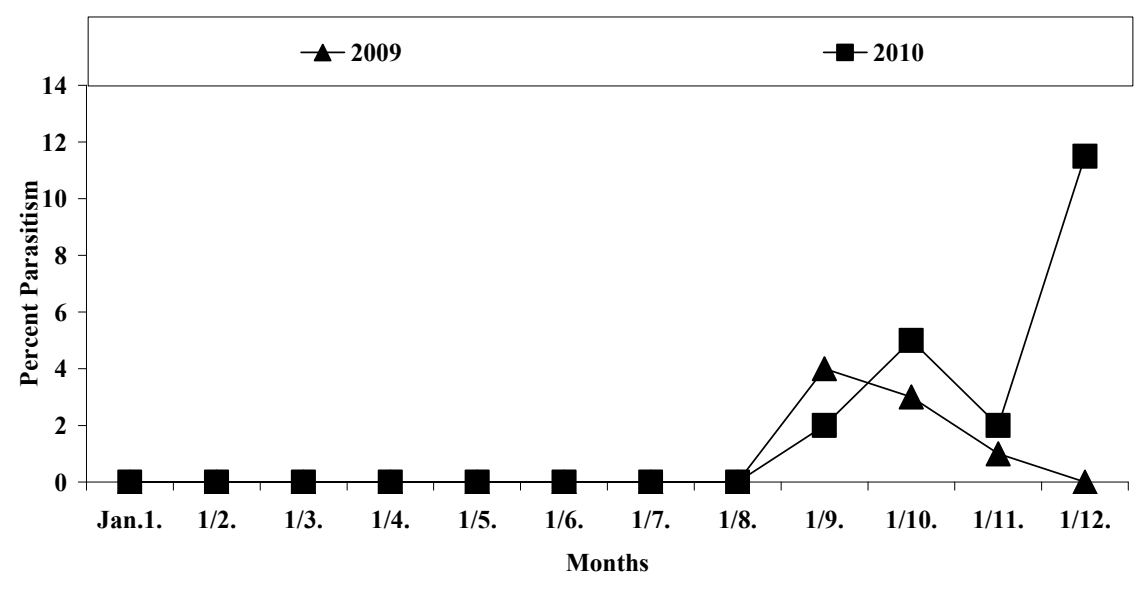

Fig. (12): Population dynamics of the predator, Exochomus flavipes associated with the latania scale, Hemiperlisia latania on olive trees in Alexandria Governorate.

Statistical analysis showed that simple correlation and regression between the population of the hyperparasitoid, $M$. leopardina and the mean number of the latania scale, $H$. lataniae were non-significant $(\mathrm{r}=0.35, \mathrm{~b}=0.31$ and $\mathrm{r}=0.19, \mathrm{~b}=0.24$ during the first and second years, respectively).

13. The predator, Orius laevigatus Fieb. (Hemiptera: Anthocoridae)

Diagnosis: Wings not covered with scales, though they may be hairy, adults are tiny (1/8 inch) black bugs with white markings at the base of the front wings (hemelytra), resulting in a band-like appearance across the body when wings are at rest.

Abundance: During the present work this predator was rarely on $H$. lataniae on mango trees in Giza. Nine and seven individuals /60 leaves and 15 twigs only collected during the first and second years, respectively (Fig.13). This species recorded here associated with the latania scale, $H$. lataniae for the first time in Egypt.

Statistical analysis showed that simple correlation and regression between the population of the predator, $O$. laevigatus and the mean number of the latania scale, $H$. lataniae were non-significant $(\mathrm{r}=0.25, \mathrm{~b}=0.23$ and $\mathrm{r}=0.16, \mathrm{~b}=0.19$ during the first and second years, respectively). 


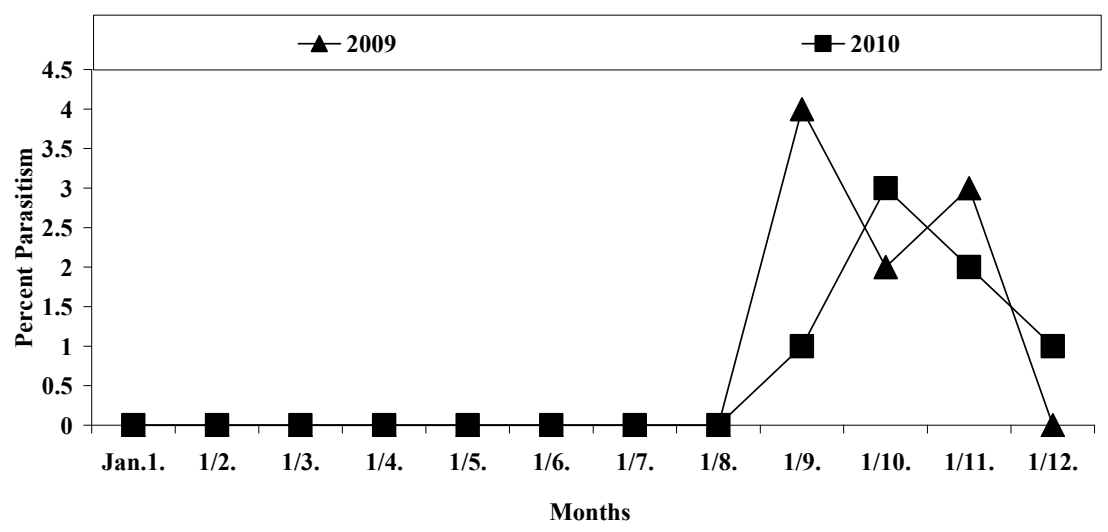

Fig. (13): Population dynamics of the predator, Orius laevigatus associated with the latania scale, Hemiperlisia latania on mango trees in Giza Governorate .

\section{The predator, Pharoscymnus various Kirsch. (Coleoptera : Coccinellidae)}

Diagnosis: Form round, strongly convex, dorsal side densely pubescent. Ground colour dark brown, each elytron with a pair of reddish/orange yellow spots, anterior spot subquadrate and larger, posterior spot roundish. Ventral side uniformly dark brown. Head quadrate, clypeal margin narrowly extending laterally over eyes, eyes not emarginate around antennal insertions. Antennae short, ten-segmented. Last segment of maxillary palpi elongate, subconical. Prosternal intercoxal process quadrate, with a pair of subparallel carinae. Postcoxal line on abdominal ventrite I incomplete, running parallel to posterior margin of ventrite I, but stopping short of lateral margin. Male genitalia as illustrated. Larva slaty grey.

Abundance: During the present work this predator was rarely on $H$. lataniae on mango trees in Giza. Nine and ten individuals/60 leaves and 15 twigs only collected during the first and second years, respectively (Fig.14). This species recorded here associated with the latania scale, $H$. lataniae for the first time in Egypt.

Statistical analysis showed that simple correlation and regression between the population of the predator, $P$. various and the mean number of the latania scale, $H$. lataniae were non-significant $(\mathrm{r}=0.28, \mathrm{~b}=0.23$ and $\mathrm{r}=0.16, \mathrm{~b}=0.20$ during the first and second years, respectively).

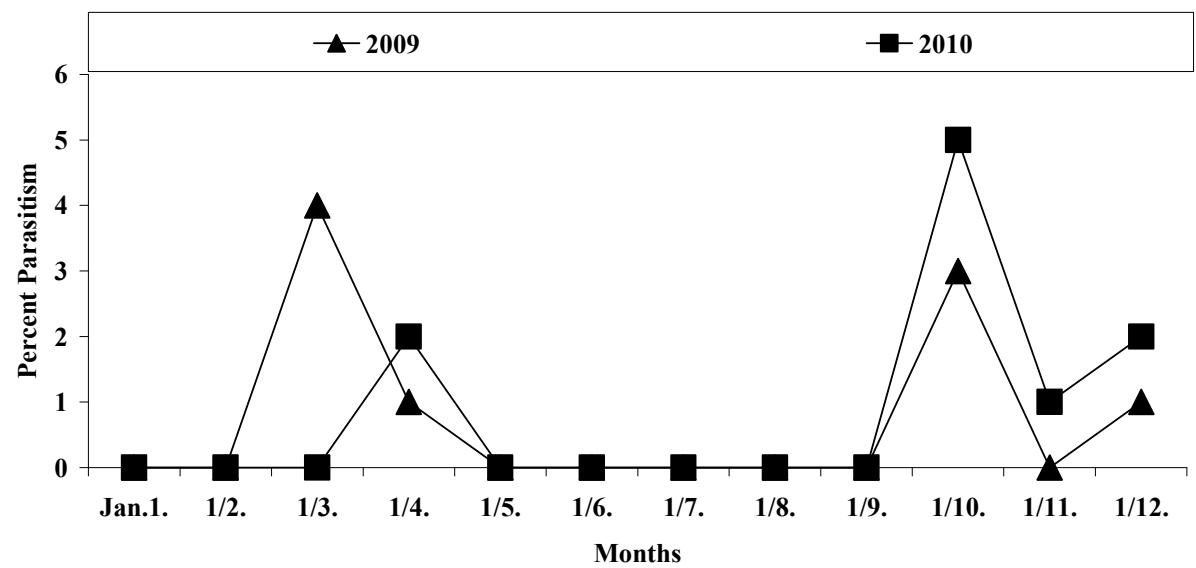

Fig. (14): Population dynamics of the predator, Pharoscymnus various associated with the latania scale, Hemiperlisia latania on olive trees in Northern Coast Governorate .

\section{The predator, Rodalia cardinals Muls (Coleoptera: Coccinellidae)}

Diagnosis: This species has three pairs of legs, tarsi appearing 3-3-3, but actually 4-44, head often concealed by pronotum, antennae short with a 3- to 6-segmented club, 
Ladybirds are small to medium in size $(2-8 \mathrm{~mm})$. Adults are very small, densely pubescent, red and black lady beetles, about 2.5-4 mm (1/16-3/16 inch) long.

Abundance: During the present work this predator was rarely on $H$. lataniae on mango trees in Giza. Twenty three and eighteen 23 and 18 individuals/60 leaves and 15 twigs only collected during the first and second years, respectively (Fig.15). This species recorded here associated with the latania scale, $H$. lataniae for the first time in Egypt.

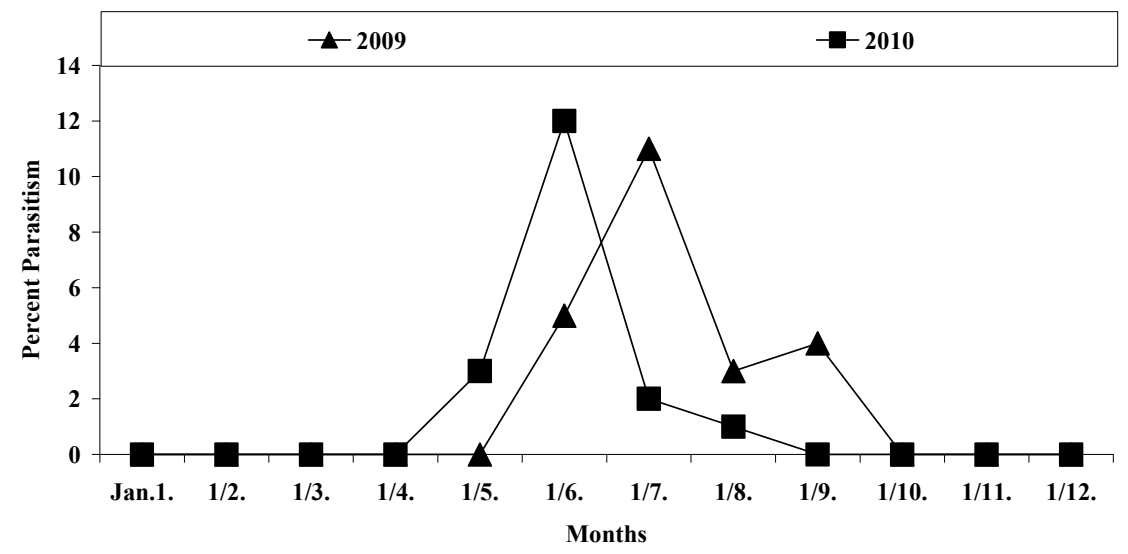

Fig. (15): Population dynamics of the predator, Rodalia cardinals associated with the latania scale, Hemiperlisia latania on mango trees in Giza Governorate .

Statistical analysis showed that simple correlation and regression between the population of the predator, $R$. cardinals and the mean number of the latania scale, $H$. lataniae were non-significant $(\mathrm{r}=0.22, \mathrm{~b}=0.25$ and $\mathrm{r}=0.25, \mathrm{~b}=0.21$ during the first and second years, respectively).

16. The predator, Scymnus syriacus Mars. (Coleoptera: Coccinellidae)

Diagnosis: Forewings are modified into hard, leathery wing-cases (called elytra) that meet in a line down the back. The hind wings are membranous, folded beneath the elytra Postcoxal line not curved forward at apex Antennae short, dorsal surface densely pubescent.

Abundance: During the present work this predator was rarely on H. lataniae on olive trees in Fayoum. Nine and seven individuals /60 leaves and 15 twigs only collected during the first and second years, respectively (Fig.16). This species recorded here associated with the latania scale, $H$. lataniae for the first time in Egypt.

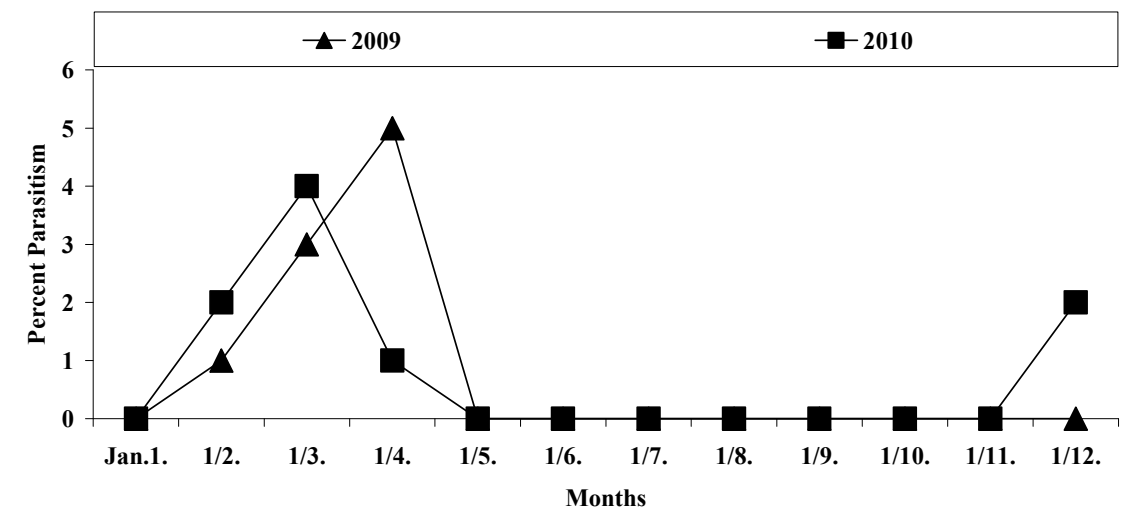

Fig. (16): Population dynamics of the predator, Scymnus syriacus associated with the latania scale, Hemiperlisia latania on olive trees in Fayoum Governorate .

Statistical analysis showed that simple correlation and regression between the population of the predator, S.syriacus and the mean number of the latania scale, $H$. 
lataniae were non-significant $(\mathrm{r}=0.20, \mathrm{~b}=0.19$ and $\mathrm{r}=0.16, \mathrm{~b}=0.17$ during the first and second years, respectively).

17. The predator, Syrphus corollae Fabricius (Diptera: Syrphidae).

Diagnosis: Adults are 6-11 millimetres $(0.24-0.43$ in) in body length. Males and females have different marking on the abdomen; males have square commas on tergites 3 and 4, whereas females have narrow commas 3 and 4, whereas females have narrow commas.

Abundance: During the present work this predator was rarely on $H$. lataniae on mango trees in Ismailia. two and one individuals/60 leaves and 15 twigs only collected during the first and second years, respectively (Fig.17). This species recorded here associated with the latania scale, $H$. lataniae for the first time in Egypt.

Statistical analysis showed that simple correlation and regression between the population of the predator, S. corollae and the mean number of the latania scale, $H$. lataniae were non-significant $(\mathrm{r}=0.23, \mathrm{~b}=0.21$ and $\mathrm{r}=0.25, \mathrm{~b}=0.26$ during the first and second years, respectively).

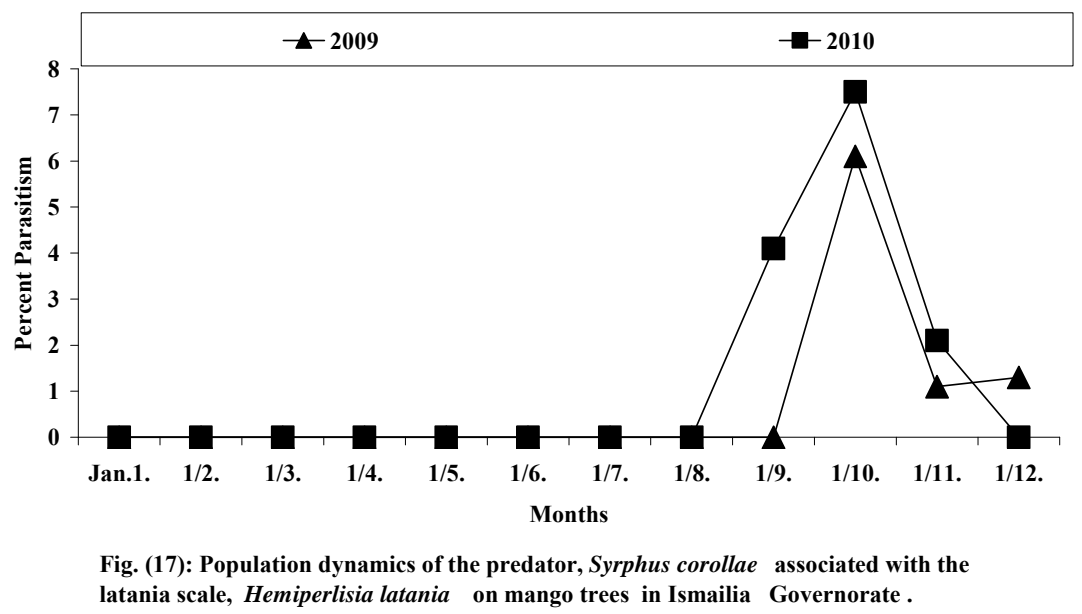

Key to the parasitoid species associated with Hemiberlesia latania (modified and adopted from Abd-Rabou, 1999)

1.Often less than $1 \mathrm{~mm}$. in length, antennae usually with three to eight segments, rarely with nine, mesoscutum with parapsidal sulci always developed, fore wing with marginal vein extremely long, ovipositor never protruding strongly $\ldots \ldots \ldots \ldots \ldots \ldots . .2$ - Often 0.5-6 mm. in length, antennae with five to twelve segments, mesoscutum with parapsidal sulci seldom developed, fore wing with marginal vein relatively short, ovipositor rarely protruding strongly caudally, male funicle two segmented Habrolepis aspidioti Compere \& Annecke

2. Antennae 8-9 segmented, fore wing without linea calva ........................

- Antennae 4-6 segmented, fore wing generally with linea calva................................4

3. Stigmal vein of fore wing with an evident asetose area proximally.....................................Encarsia aurantii (Howard)

-Stigmal vein of fore wing without an evident asetose area proximally. At least one small seta proximal to the stigmal vein......Encarsia lounsburyi (Berlese \& Paoli)

4. Propodeum short, subequal to metanotum, without crenulae,, Antennal scape twice as long as wide, with a single band; fore wing narrow, not less than twice as long as wide, with pattern Apex of fore wing without infuscate band in middle, mesoscutum 4 setae. Marietta leopardina Motschulsky -Propodeum long, considerably longer than metanotum, bearing marginal crenulae................................................................5 
5. Propodeal crenulae large and overlapping Body setae slender and pale; mid lobe usually with 10-12 setae; fore wing proximad of linea calva with 30-50 setae Aphytis lingnanensis Comepre

-Propodeal crenulae (large or small) non-overlapping, ..6 6. Occiput with a fuscous to black bar on each side of foramen, the mouth margin and malar sulcus sometimes fuscous, first segment of funicle small, triangular and smaller than second segment of funicle.

Aphytis chilensis Howard

- Occiput without such bars on sides of foramen, mouth margin and malar sulcus usually not fuscous

7. Thoracic sterna dusky, propodeal crenulae rounded. Biparental..................................... Aphytis mytilaspidis (Le Baron)

- Thoracic sterna immaculate. Uniparental........... Aphytis aonidiae (Mercet)

Key to the predator species associated with Hemiberlesia latania

1. Four membranous wings, with the forewings and hindwings about the same size, and with many veins. Adult green lacewings are pale green, about 12-20 mm long, with long antennae and bright, golden eyes. They have large, transparent, pale green wings and a delicate body. Chrysoperla carnea (Stephens)

- Wings different .2

2. Their body is covered with short hairs Pharoscymnus various Kirsch.

-Their body is covered with different

3. Wings not covered with scales, though they may be hairy, adults are tiny (1/8 inch) black bugs with white markings at the base of the front wings (hemelytra), resulting in a band-like appearance across the body when wings are at rest.............. Orius sp. - Forewings are modified into hard, leathery wing-cases (called elytra) that meet in a line down the back. The hind wings are membranous, folded beneath the elytra.

4. Postcoxal line on first abdominal sternum curved forward at apex complete Exochomus flavipes (Thunberg)

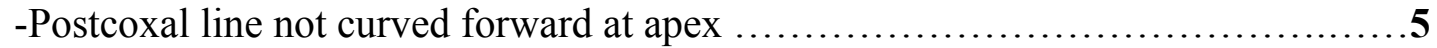

5. Antennae short, dorsal surface densely pubescent ......Scymnus syriacus Marseul - Antennae long ..........................................................6 6. Antennae 8-segmented,the ladybird was bright orange in colour with dark edges on the wing-cover base. Chilocorus bipustulatus (L.)

- Antennae7-segmented, Coccinella undecimpunctata $\mathrm{L}$.

\section{REFERENCES}

Abd-Rabou, S. (1997). Parasitoids attacking some species of scale insects (Homoptera: Coccoidea: Diaspididae) in Egypt. Proceeding of the First Scientific Conference of Agricultural Sciences, Faculty of Agric. Assiut Univ., Vol. II, 727-736.

Abd-Rabou, S. (1999). Parasitoids attacking the Egyptian species of armored scale insects (Homoptera : Diaspipidae). Egypt J. Agric. Res., 77(3): 1113-1129.

Abd-Rabou, S. (2000). Host range of Encarsia lounsburyi (Hymenoptera: Aphelinidae) as a parasitoid of armored scale insects (Homoptera: Diaspididae) in Egypt. The Second Scientific Conference of Agric. Sci., Assiut, Vol. II. 655-659.

Abd-Rabou, S. (2001). The effect of augmentative releases of indigenous parasitoids on populations of Parlatoria oleae (Colveé) (Hemiptera: Coccoidea) on Olive groves in Egypt. Boll.Zool.agr. Bachic., Ser II, 33(3): 473-481. 
Abd-Rabou, S. (2002). Revision of Aphelinidae (Hymenoptera) from Egypt. Second International Conference, Vol. of Plant Protection Research Institute, 1: 262-290.

Abd-Rabou, S. (2003). Host range and distribution of Marietta leopardina (Hymenoptera: Aphelinidae), a hyperparasitoid of hemipterous and hymenopterous species in Egypt. Egyptian, J. of Agric. Res. 81(2): 555-562.

Abd-Rabou, S. (2006). Hymenopterous parasitoids as a bioagent for controlling homopterous insects in Egypt. Egypt. Adv. Agric. Res. In Egypt, 6 (1): 1-65.

Abd-Rabou, S. and Hayat, M. (2003). A synopsis and key to the Egyptian species of Aphytis Howard (Hymenoptera : Aphelinidae) parasitoids of diaspidid scale insects (Homoptera : Diaspididae). Acta Phytopathologica et Entomologica Hungarica, 38 (3-4):357-363.

Danzig, E.M. and G. Pellizzari, (1998). Diaspididae. In: F. Kozár (ed.), Catalogue of Palaearctic Coccoidea. Hungarian Academy of Sciences. Akaprint Nyomdaipari Kft., Budapest, Hungary: 172-370.

Davidson, J.A. and Miller, D.R. (1990). Ornamental plants. In: D. Rosen (ed.), Armoured scale insects, their biology, natural enemies and control. Vol. 4B. Elsevier, Amsterdam, the Netherlands: 603-632.

El-Minshawy, A.M., El-Sawaf, S.K., Hammad, S.M. and A. Donia, (1971). The biology of Hemiberlesia lataniae (Sign.) in Alexandria District. Bulletin of the Entomological Society of Egypt 55: 461-467.

El-Minshawy, A.M., El-Sawaf, S.K., Hammad, S.M. and Donia, A. (1974). Survey of the scale insects attacking fruit trees in Alexandria district. (Part I: Fam. Diaspididae; subfam. Diaspidinae, tribe Aspidiotini). Alexandria Journal of Agricultural Research, 22: 223-232.

Hafez, M. (1988). Population fluctuations on parasites of California red scale, Aonidiella aurantii (Mask) (Homoptera : Diaspididae) in Alexandria. J. App. Ent., 106 (2): 183-187.

Hill, M. G.; Allan, D. J.; Henderson, R. C. and Charles, J. G. (1993). Introduction of armoured scale predators and establishment of the predatory mite Hemisarcoptes coccophagus (Acari: Hemisarcoptidae) on latania scale, Hemiberlesia lataniae (Homoptera: Diaspididae) in kiwifruit shelter trees in New Zealand. Bulletin of Entomological Research, 83:369-376.

Kosztarab, M. (1996). Scale insects of north-eastern North America. Identification, biology, and distribution. Virginia Museum of Natural History, Martinsville, Virginia, USA. $650 \mathrm{pp}$.

Nakahara, S. (1982). Checklist of the armored scales (Homoptera: Diaspididae) of the conterminous United States. Animal and Plant Health Inspection Service, Plant Protection and Quarantine, United States Department of Agriculture, Washington, D.C., USA. $110 \mathrm{pp}$.

Noyes, J. S. (1982). Collecting and preserving chalcid wasps (Hymenoptera: Chalcidoidea). Journal of Natural History, 16: 315-334.

Priesner, A. and Hosny, M. (1940). Notes on parasites and predators of Coccidae and Aleyrodidae in Egypt. Bull. Soc. Ent. Egypt, 24: 58-70.

Stoetzel, M. B. and Davidson, J. A. (1974). Biology, morphology and taxonomy of immature stages of 9 species in the Aspidiotini (Homoptera: Diaspididae). Annals of the Entomological Society of America 67: 475-509.

Williams, J. R. and Greathead, D. J. (1990). Sugar Cane. In: D. Rosen (ed.), Armoured scale insects, their biology, natural enemies and control. Vol. 4B. World Crop Pests. Elsevier, Amsterdam, the Netherlands: 563-578.

Williams, D. J. and Watson, G. W. (1988). The scale insects of the tropical South Pacific region. Part 1 The armoured scales (Diaspididae). CAB International, Wallingford, UK. $290 \mathrm{pp}$. 


\section{ARABIC SUMMARY}

$$
\begin{aligned}
& \text { الأعداء الحيوية لحشرة اللاتانيا القشرية فى مصر } \\
& \text { منى مصطفى - شعبان عبدربه } \\
& \text { معهد بحوث وقاية النباتات ـ مركز البحوث الزعبان عباعيةـ الدقيـ الجيزة- مصر }
\end{aligned}
$$

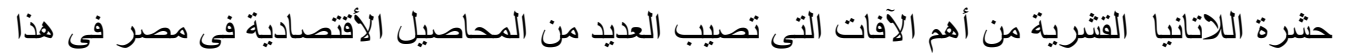

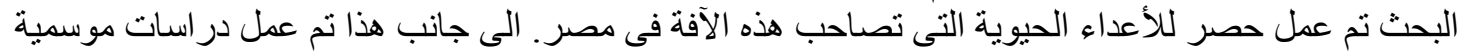
على تعداد هذه الأعداء الحيوية على محاصيل و آماكن مختلفة. وقد أنض أتضح من النتائج أن هذه الأفة يتطفل عليها

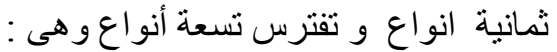

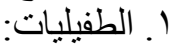

Aphytis aonidiae (Mercet), Aphytis chilensis Howard, Aphytis lingnanensis Comepre, Aphytis mytilaspidis (Le Baron), Encarsia aurantii (Howard), Encarsia lounsburyi (Berlese \& Paoli), Marietta leopardina Motschulsky and Habrolepis aspidioti Compere \& Annecke

Chilocorus bipustulatus L. Chrysoperlla carnae Steph., Coccinella undecimpunctata L., Exochomus flavipes Thunb., Orius laevigatus Fieb., Pharoscymnus various, Rodalia cardinals Muls., Scymnus syriacus Mars., Syrphus corollae Fabricius وقد أتضح من النتائج ان طفيل Habrolepis aspidioti من الطفيليات السائدة لهذه الآفة على المانجو

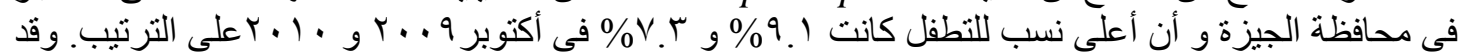

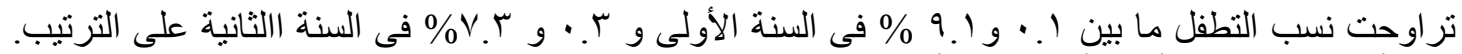

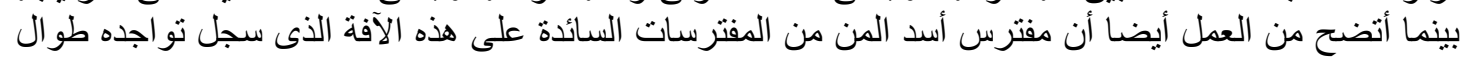

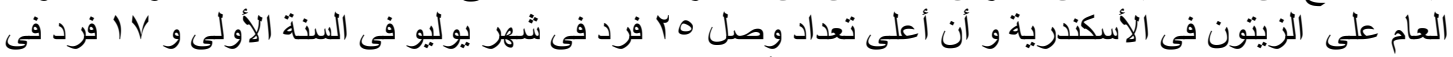

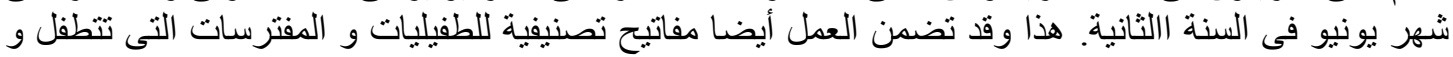

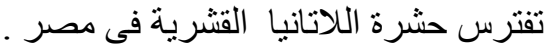

